\title{
Morphological, Molecular, and Growth Characteristics of a Cryptic Species, Strombidium parasulcatum n. sp. (Alveolata: Ciliophora: Oligotrichida)
}

\author{
Sheng-Fang Tsai1,2, Meng-Lun Lee ${ }^{1}$ and Kuo-Ping Chiang ${ }^{1 *}$ \\ ${ }^{1}$ Institute of Marine Environment and Ecology, National Taiwan Ocean University, Keelung, Taiwan, ${ }^{2}$ Center of Excellence \\ for the Oceans, National Taiwan Ocean University, Keelung, Taiwan
}

A new marine planktonic ciliate from Taiwan, Strombidium parasulcatum sp. $\mathrm{n}$., is described based on live observations, protargol staining, and molecular data. Its morphological characters are similar to those of Strombidium sulcatum Claparède and Lachmann, 1859 sensu Song et al., 2000 but differ from S. sulcatum sensu Fauré-Fremiet, 1912 and sensu Fauré-Fremiet and Ganier, 1970 by several morphological characters. The 18S rRNA gene sequences of the two forms display 76

OPEN ACCESS

Edited by:

Xinpeng Fan,

East China Normal University, China

Reviewed by:

Wen Song,

Shandong University, China

Dapeng Xu,

Xiamen University, China

*Correspondence:

Kuo-Ping Chiang

kpchiang@mail.ntou.edu.tw

Specialty section:

This article was submitted to

Aquatic Microbiology,

a section of the journal

Frontiers in Microbiology

Received: 04 September 2021 Accepted: 16 December 2021

Published: 10 February 2022

Citation:

Tsai S-F, Lee M-L and Chiang K-P (2022) Morphological, Molecular, and Growth Characteristics of a

Cryptic Species, Strombidium parasulcatum n. sp. (Alveolata:

Ciliophora: Oligotrichida).

Front. Microbiol. 12:770768. doi: 10.3389/fmicb.2021.770768 base pair differences (about 5\%), indicating that they should be considered separate species. The highest observed specific growth rates of $S$. parasulcatum in culture were 1.79 day $^{-1}$ over 1 day and 1.52 day $^{-1}$ over 2 days, both starting at day 5 . Bacteria appear to be an important food resource for the cultivation of this mediumsized oligotrich ciliate. This and other recent studies suggest that cryptic species may be common in the genus Strombidium, and an integrative approach including morphological, ecological, and molecular data should be used to address this question.

Keywords: ciliary pattern, protozoa, phylogeny, Strombidiidae, taxonomy

\section{INTRODUCTION}

The oligotrich (s. l.) ciliates are a dominant group in the marine microzooplankton. They serve as an effective link between the microbial loop and the grazing food chain due to their high abundance and growth rate (Maeda and Carey, 1985; Maeda, 1986; Fileman and Leakey, 2005; Bojanić et al., 2006; Pierce and Turner, 1992; Agatha, 2011a). Knowledge of their functional diversity is important for understanding their roles in nature (Mitra et al., 2016). With regard to their taxonomic diversity, observations of specimens in vivo and following silver staining are regarded as essential for accurate species identification and circumscription (Warren et al., 2017).

Currently, the number of valid oligotrich (s. str.) species amounts to about 120 (Agatha and Strüder-Kypke, 2014), but recent studies revealed that numerous cryptic species in oligotrichs exist, suggesting that their biodiversity is greater than previously assumed and highlighting the need for further investigations of their taxonomy (McManus et al., 2010; Agatha, 2011b). Although live observations are indispensable for a good description of oligotrich species, they are unfortunately lacking in many publications. Due to the phenotypic plasticity and lack of reliable morphological features for many oligotrich ciliates, it is often difficult or even impossible to separate cryptic species based on morphology alone (Katz et al., 2005; Liu et al., 2017). 
Hence, the small subunit (18S) rRNA gene is increasingly being sequenced to supplement morphological observations. The recent treatments of new or poorly known taxa suggest that integrating molecular and morphological data provides a reliable method to distinguish similar species (Modeo et al., 2003; Agatha et al., 2005; Agatha and Strüder-Kypke, 2007; Strüder-Kypke and Lynn, 2008; Tsai et al., 2008, 2010, 2015; Liu et al., 2009, 2011a,b, 2015, 2017; Kim et al., 2010; McManus et al., 2010; Xu et al., 2011; Chen et al., 2013; Qu et al., 2015; Song et al., 2015a,b).

The species in the genus Strombidium, with a horizontal girdle kinety, a longitudinal ventral kinety, and the oral primordium posterior to the girdle kinety, exhibit great biodiversity (Agatha and Strüder-Kypke, 2014). Phylogenetic analyses based on genetic data have revealed the nonmonophyly of the genus Strombidium, producing highly variable tree topologies with very low support values (Gao et al., 2009; Zhang et al., 2010; Li et al., 2013; Agatha and Strüder-Kypke, 2014). The phylogenetic relationships of members of this genus demonstrates the need for more gene sequences of properly identified oligotrich species. Recent studies also suggest that cryptic species in the genus Strombidium may be common, highlighting the need to conduct investigations using multiple taxonomic technologies (McManus et al., 2010).

Strombidium parasulcatum n. sp., which is very similar in morphological characters to Strombidium sulcatum Claparède and Lachmann, 1859 (sensu Song et al., 2000), is here described based on live observation, protargolimpregnated material, and $18 \mathrm{~S}$ rRNA gene sequences of specimens collected from the northeastern coastal waters of Taiwan in 2011. In addition, we present its growth rates and report that bacteria appear to be an important food resource for this oligotrich ciliate. By combining morphological, molecular, and ecological data, we were able to identify and circumscribe this cryptic species and clarify its phylogeny position.

\section{MATERIALS AND METHODS}

\section{Sample Collection, Observation, and Identification}

Plankton samples were taken with a $20-\mu \mathrm{m}$ mesh plankton net from the coastal waters of northeastern Taiwan $\left(25^{\circ} 08^{\prime} 30^{\prime \prime} \mathrm{N}\right.$; $121^{\circ} 47^{\prime} 42^{\prime \prime}$ E) on September 8, 2011. Water temperature and salinity were about $27^{\circ} \mathrm{C}$ and $33 \mathrm{psu}$, respectively.

The behavior of the specimens was observed in a Petri dish (about $9 \mathrm{~cm}$ across; water depth about $1 \mathrm{~cm}$ ) under a dissecting microscope (40-70×; Nikon, SMZ-U). After isolation, specimens were observed, using bright field and differential interference contrast microscopy (Nikon, OPTIPHOT-2). Ten living cells were studied at magnifications of $125-1,250 \times$. Illustrations of live specimens were made from free-hand drawings and photomicrographs. Protargol impregnation followed the protocol of Song and Wilbert (1995). Protargol-stained cells were drawn, using a camera lucida (Nikon, Y-IDT). Terminology and systematics follows Agatha and Riedel-Lorjé (2006).

\section{Culture}

The monoclonal S. parasulcatum n. sp. was cultured in Petri dishes with bacteria as prey in the water column at $25^{\circ} \mathrm{C}$ on a 12:12 h light/dark cycle for 45 days. The salinity of the culture medium was $33 \mathrm{psu}$, matching the ambient salinity. To observe changes in the abundance of ciliates and bacteria during the culture period, a source culture in a $500-\mathrm{ml}$ polycarbonate (PC) bottle was prepared by putting $500 \mathrm{ml}$ of $0.2-\mu \mathrm{m}$ filtered sea water into the bottle along with five grains of rice to raise bacteria. Two days later, when bacteria had reached a sufficient concentration, 500 cells of $S$. parasulcatum n. sp. were added to the bottle. Subsamples $(10 \mathrm{ml})$ were then collected in the noon at 1-day intervals after gently but thoroughly mixing the PC bottle.

To count bacteria, subsamples of $1 \mathrm{ml}$ culture sea water each were fixed immediately by adding glutaraldehyde to a final concentration of $1 \%$ and then were filtered onto $0.2-\mu \mathrm{m}$ black Nuclepore filters under low pressure $(<100 \mathrm{~mm} \mathrm{Hg}$ ) with a $0.45-$ $\mu \mathrm{m}$ pore size Millipore filter used as a backing pad to obtain an even distribution of cells. Bacteria left on the filter membranes were then stained with 4'6-diamidino-2-phenylindole (DAPI) at a final concentration of $1 \mu \mathrm{g} \mathrm{ml}^{-1}$ (Porter and Feig, 1980) and counted under an epifluorescence microscope at 1,000× magnification (Nikon Optiphot-2, Japan). For the enumeration of S. parasulcatum n. sp., a 9-ml subsample of the culture was fixed with Lugol's solution to a final concentration of $5 \%$, concentrated following the Utermöhl method (Hasle, 1978), and counted under an inverted microscope (Nikon-TMD 300, Japan) at $200 \times$ or $400 \times$ magnifications.

\section{Extraction, Amplification, and Sequencing of rRNA Gene}

DNA extraction was done according to Tsai et al. (2008, 2010). Polymerase chain reaction (PCR) was performed in a buffer containing $3 \mathrm{mM} \mathrm{MgCl} 2,0.25 \mathrm{mM}$ dNTP, $10^{-3} \mathrm{mM}$ forward (5'-AAC CTG GTT GAT CCT GCC AGT-3') and reverse (5'TCC TTC TGC AGG TTC ACC TAC-3') primers (Medlin et al., 1988), and SuperTaq polymerase (HT Biotechnology, Cambridge, United Kingdom). PCR involved one cycle of $5 \mathrm{~min}$ at $95^{\circ} \mathrm{C} ; 35$ cycles of $30 \mathrm{~s}$ at $95^{\circ} \mathrm{C}, 30 \mathrm{~s}$ at $56^{\circ} \mathrm{C}$, and $2 \mathrm{~min}$ at $72^{\circ} \mathrm{C}$; and a final cycle of $10 \mathrm{~min}$ at $72^{\circ} \mathrm{C}$. The PCR fragments of three clones were ligated into a pGEM-T vector (Promega, Madson, WI, United States) and sequenced by ABI Prism 3730.

\section{Phylogenetic Analyses}

All 18S rRNA gene sequences used for phylogenetic analysis were obtained from GenBank/EMBL databases, including 18 choreotrichids, 46 oligotrichids, and 3 hypotrich species as outgroup (see Figure $\mathbf{1}$ for accession numbers). The alignment of these sequences with that of $S$. parasulcatum was performed, using CLUSTAL W (Thompson et al., 1994). Ambiguous nucleotide positions at the beginnings and ends of fragments were deleted, thus resulting in a data set consisting of 1,293 nucleotide positions. For the phylogenetic analysis, MODELTEST (Posada and Crandall, 1998) was employed to find the model (GTR $+\Gamma$ model) of DNA substitution that best fit our data. The parameters (nst $=6$, rates $=\gamma, n=4$, 


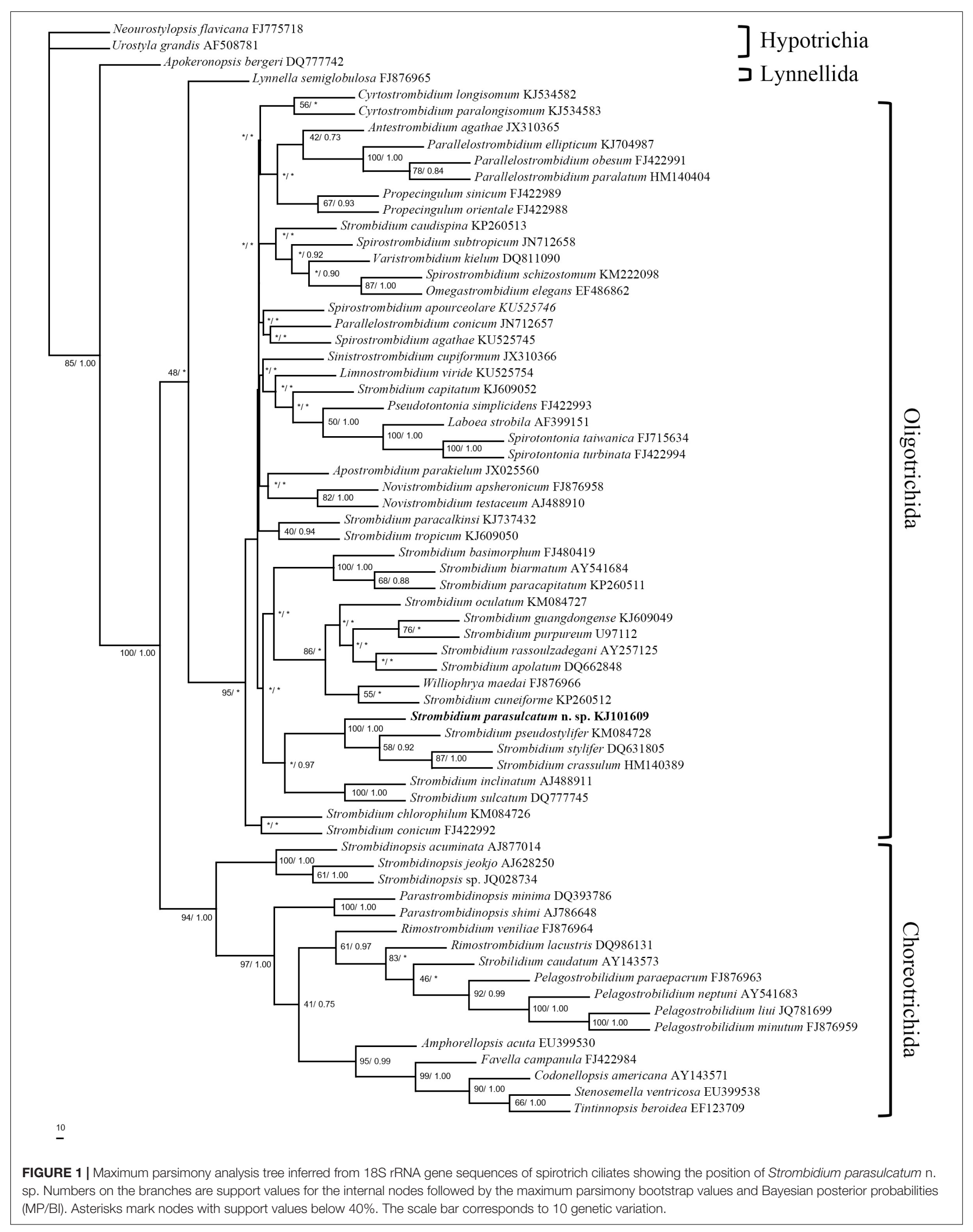


and temperature $=0.2$ ) were implemented into MrBayes ver. 3.1.2 (Huelsenbeck and Ronquist, 2001). A Bayesian Inference analysis (BI) was performed over 4,000,000 generations with two simultaneous and completely independent analyses starting from different random trees. The posterior probability of a phylogeny out of 75,001 trees, approximated via the Markov chain Monte Carlo method with sampling every 50th generation (tree), was computed, with the first 5,003 trees being discarded as burnin. A maximum parsimony (MP) analysis was performed with PAUP* ver. 4.0b10 (Swofford, 2002).

\section{RESULTS}

\section{Strombidium parasulcatum n. sp.}

Cell size in vivo is $40-50 \times 30-40 \mu \mathrm{m}$, usually $45 \times 35 \mu \mathrm{m}$; after protargol impregnation, it becomes slightly shorter, viz., 29$41 \times 27-40 \mu \mathrm{m}$, usually $35 \times 34 \mu \mathrm{m}$ (Table 1). Its shape is slightly variable, generally broadly obconical to ellipsoidal; circular in cross-section, widest in equatorial area, and slightly tapered in posterior half, with posterior end broadly rounded to bluntly pointed (Figures 2A,E,F, 3A,B,E). Apical protrusion is about $5 \mu \mathrm{m}$ high in vivo (Figures 2A, 3A,B,D), sometimes undetectable (Figure 3C). Buccal cavity is shallow but wide, obliquely extending posteriorly to $25 \%$ of cell length (Figures $2 \mathrm{~A}, \mathbf{E}$ and $\mathbf{3 A}, \mathbf{B}, \mathbf{J}), 15 \mu \mathrm{m}$ in width. There is buccal lip on the right side of the oral cavity, forming small longitudinal ridge ventrally (Figure 2A). Macronucleus in left cell half is $10-28 \times 8-14 \mu \mathrm{m}$ in size after protargol staining, variable in shape from spherical to bilobed shape, typically ellipsoidal, containing numerous nucleoli 1-2 $\mu \mathrm{m}$ in diameter (Figures 2A,D,F, 3J-N). Neither a contractile vacuole nor the cytopyge is recognized. Cortical platelets (hemitheca) posterior to girdle kinety are polygonal, about $3 \mu \mathrm{m}$ across (Figures 2A, 3C). Cell surface posterior to girdle kinety is distinctly distended in live and prepared cells, except for the region around ventral kinety where a furrow formed. Extrusomes are prominent in vivo, acicular, about $15 \times 0.5 \mu \mathrm{m}$ in size, with rounded anterior and pointed posterior end, closely bundled posterior to the girdle kinety, attached probably in a single row to shallow bulge $\sim 4 \mu \mathrm{m}$ anterior to girdle kinety, posteriorly extending obliquely into cytoplasm (Figures 2A,B, 3A,F-H); attachment sites are visible as dotted stripe in protargol-impregnated cells (Figure 3L) but sometimes not observed in over-bleached specimens (Figure 3J). Oral primordium is posterior to girdle kinety and left of ventral kinety (Supplementary Figure 1). Cytoplasm is colorless, full of lipid droplets about $3 \mu \mathrm{m}$ in diameter (Figures 3A,B). Food vacuoles contain diatoms when cells are collected in the sampling site. They rotate about the main cell axis while swimming (Figure 2C). Cell is bursting easily when water temperature increases or when in contact with water surface.

Somatic cilia are $2-3 \mu \mathrm{m}$ long in vivo, arranged in a girdle kinety and ventral kinety. Girdle kinety, positioned in posterior one-third ( $\sim 65 \%$ ), composed of $48-64$ horizontally orientated, continuously arranged dikinetids, each has associated a cilium only with its left basal body (Figures 2A,E,F, 3F,J,K). Ventral kinety, $\sim 10 \mu \mathrm{m}$ posterior to girdle kinety, extends meridionally in argyrophilic furrow on ventral side occupying posterior onefourth of cell length, composed of four to eight meridionally orientated dikinetids, each with its anterior basal body ciliated (Figures 2A,E, 3J).

Oral apparatus occupies anterior cell portion. Adoral zone of membranelles surrounds apical protrusion, about $28 \mu \mathrm{m}$ across, terminates about $30 \%$ posterior to anterior end of cell, divided into a collar and buccal zone portion (Figures 2E,F, 3J,K). The collar portion is distinctly slanted leftwards and decreases in height from right to left in protargolstained specimens, composed of 15 membranelles, on average, continuous with buccal portion comprising nine membranelles. Collar membranelles are composed of three rows of basal bodies, $8 \mu \mathrm{m}$ in length, with cilia up to $25 \mu \mathrm{m}$ long, orientated perpendicular to the main axis in swimming specimens (Figures 2A, 3D). Argentophilic fibers present between and parallel to collar membranelles (Figure 2F). Collar membranelles are about $2 \mu \mathrm{m}$ apart (Figure 3E). Buccal membranelles are composed of three rows of basal bodies, except for the proximal most one with two rows of basal bodies, decreasing in width from $5 \mu \mathrm{m}$ in distal portion to about $2 \mu \mathrm{m}$ in proximal zone portion (Figures 2A,E, 3A,B,J). The endoral membrane is composed of a single row of basal bodies (probably with stichomonad structure) and extends longitudinally on the inner wall of the buccal lip (Figure 2E).

\section{Cultivation}

During a 45-day cultivation, the average and minimum concentrations of bacteria were $1.5 \times 10^{7}$ and $8.6 \times 10^{6}$ cells $\mathrm{ml}^{-1}$, respectively (Supplementary Figure 2A). The growth curve of $S$. parasulcatum n. sp. performed a maximum growth rate at day 5 shown in dashed line (Supplementary Figure 2B). Strombidium parasulcatum n. sp. showed its highest 1- and 2-day specific growth rates, 1.79 and 1.52 day $^{-1}$, respectively at day 5; the growth rate decreased thereafter, even falling below 0 day $^{-1}$ (Supplementary Figure 2C).

\section{S rRNA Gene Sequence and Phylogenetic Analyses}

The 18S rRNA gene sequence of $S$. parasulcatum n. sp. (GenBank accession no. KJ101609) was 1,729 nucleotides long. The sequences of the three clones were identical. A pairwise distance matrix of six morphologically similar Strombidium species was generated, using the p-distance method (Table 2). Nucleotide pairwise distances ranged from 0.0000 (the variation between S. sulcatum and Strombidium inclinatum) to 0.0459 (the variation between S. parasulcatum and S. sulcatum and S. inclinatum, respectively). With the differences of $76 \mathrm{bp}$, it was $95 \%$ similar to both of S. sulcatum (DQ777745) sampled by Gao et al. (2009) in Qingdao, China, and S. inclinatum (AJ488911) sampled by Modeo et al. (2003) in Leghorn, Italy. The sequences similarities between $S$. parasulcatum and Strombidium pseudostylifer/Strombidium stylifer/Strombidium crassulum were all $98 \%$, with 28 bp difference.

The topologies inferred, using BI and MP, were basically congruent, and only the MP tree is shown (Figure 1). The 
TABLE 1 | Meristic and morphometric characterization of Strombidium parasulcatum n. sp. based on protargol-impregnated specimens.

\begin{tabular}{|c|c|c|c|c|c|c|c|c|}
\hline Character & $\bar{x}$ & $\mathbf{M}$ & SD & SE & CV & Min & Max & $\mathbf{n}$ \\
\hline Cell, length & 35.4 & 36.0 & 3.7 & 0.7 & 0.10 & 29.0 & 41.0 & 25 \\
\hline Cell, width & 33.8 & 34.0 & 4.0 & 0.8 & 0.12 & 27.0 & 40.0 & 25 \\
\hline Cell length/width, ratio & 1.1 & 1.0 & 0.1 & 0.0 & 0.07 & 0.9 & 1.2 & 25 \\
\hline Anterior cell end to buccal vertex, distance & 12.2 & 12.0 & 2.2 & 0.5 & 0.18 & 8.0 & 18.0 & 21 \\
\hline Buccal cavity, width & 15.0 & 14.0 & 2.8 & 0.6 & 0.19 & 11.0 & 20.0 & 25 \\
\hline Cell length/distance anterior cell end to buccal vertex, ratio & 3.0 & 3.0 & 0.7 & 0.1 & 0.22 & 2.1 & 5.0 & 21 \\
\hline Anterior cell end to macronucleus, distance & 14.1 & 14.0 & 2.8 & 0.6 & 0.20 & 10. & 21.0 & 25 \\
\hline Anterior cell end to girdle kinety, distance & 23.1 & 24.0 & 3.3 & 0.7 & 0.14 & 16.0 & 28.0 & 25 \\
\hline Macronucleus, length & 18.9 & 18.0 & 4.1 & 0.8 & 0.22 & 10.0 & 28.0 & 25 \\
\hline Macronucleus, width & 10.6 & 10.0 & 1.5 & 0.3 & 0.14 & 8.0 & 14.0 & 25 \\
\hline Micronucleus, number & 1.0 & 1.0 & 0.0 & 0.0 & 0.00 & 1.0 & 1.0 & 9 \\
\hline Micronucleus, diameter & 3.4 & 3.0 & 0.7 & 0.2 & 0.21 & 3.0 & 5.0 & 9 \\
\hline Adoral zone of membranelles, outer diameter & 27.9 & 28.0 & 2.6 & 0.5 & 0.09 & 22.0 & 32.0 & 25 \\
\hline Collar membranelles, number & 14.5 & 14.0 & 0.8 & 0.2 & 0.05 & 13.0 & 16.0 & 25 \\
\hline Collar membranelles, distance between bases & 2.1 & 2.0 & 0.3 & 0.1 & 0.16 & 2.0 & 3.0 & 25 \\
\hline Buccal membranelles, number & 8.6 & 9.0 & 1.2 & 0.3 & 0.13 & 7.0 & 10.0 & 19 \\
\hline Girdle kinety, number of dikinetids & 55.1 & 56.0 & 4.2 & 1.0 & 0.08 & 48.0 & 64.0 & 19 \\
\hline Ventral kinety, length & 6.2 & 6.0 & 1.1 & 0.3 & 0.17 & 4.0 & 8.0 & 15 \\
\hline Ventral kinety, number of dikinetids & 6.9 & 7.0 & 1.2 & 0.3 & 0.18 & 4.0 & 8.0 & 17 \\
\hline
\end{tabular}

Measurements in micrometers.

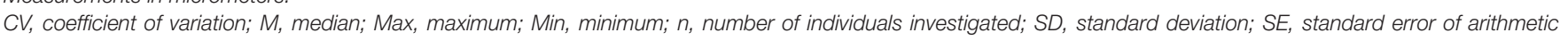
mean; $\bar{x}$, arithmetic mean.

new species formed a clade with S. crassulum, S. pseudostylifer, and S. stylifer (MP, 100\%; BI, 1.00) that was sister to the clade including S. sulcatum and S. inclinatum (MP, 36.5\%; BI, 0.97).

\section{DISCUSSION}

Strombidium sulcatum was first observed by Claparède and Lachmann (1859). In a revision of the species, Montagnes et al. (1990) proposed that the works of Fauré-Fremiet and colleagues collectively characterized S. sulcatum and diagnosed the species according to the descriptions of Fauré-Fremiet (1912) and FauréFremiet and Ganier (1970).

Song et al. (2000) found that a detailed redescription concerning the morphology in vivo and infraciliature of S. sulcatum is still necessary because of its high variability in many respects based on the observation of a population from Yellow Sea and suggested an improved diagnosis. Later, its $18 \mathrm{~S}$ rRNA gene sequences were extracted accompanied with the identifications investigated in vivo and impregnated with protargol (Zhang et al., 2010).

With the improved knowledge of strombidiid structure (Montagnes and Lynn, 1991; Foissner, 1994) and the ready availability of better microscopes, Granda and Montagnes (2003) re-examined Fauré-Fremiet's silver-stained material collected from the northeastern Atlantic Ocean, which morphologically agree with those presented by Fauré-Fremiet (1912) and FauréFremiet and Ganier (1970) (slides made in the 1950s and 1960s), deposited the type material from Fauré-Fremiet's slide, and provided authoritative data, annotating their observations with illustrations and micrographs and thereby putting a halt to all discussions about the identity of the species.

Some morphological differences between $S$. sulcatum populations reported from the northeastern Atlantic Ocean (Fauré-Fremiet and Ganier, 1970; Fauré-Fremiet, 1912) and those from the Yellow Sea (Song et al., 2000) were observed in the shape of macronucleus and the transient nature of the protrusion. Granda and Montagnes (2003) suggested not to make a distinction between these two populations until more data are available on this potentially cosmopolitan species (Agatha et al., 2021). Even though these two characters do not have high weight in species level to separate Strombidium species, it is not insufficient to make the conclusion that they belong to another, pseudo-cryptic species. However, we take all the similar forms as a complex of S. sulcatum and wait for future solution.

\section{Comparison With Similar Congeners}

Seven congeners are similar or close to $S$. parasulcatum n. sp., viz., S. crassulum Petz et al., 1995, S. inclinatum Montagnes et al., 1990, S. pseudostylifer Song et al., 2015a, S. stylifer Levander, 1894, S. sulcatum Claparède and Lachmann, 1859 sensu Granda and Montagnes, 2003, S. sulcatum sensu Song et al., 2000, and Strombidium suzukii Xu et al., 2009, according to the body shape or the close relationship in the phylogenetic tree (Montagnes et al., 1990; Petz et al., 1995; Song et al., 2000, 2015a,b; Granda and Montagnes, 2003; Xu et al., 2009; Table 3 and Figure 4). Here, we ignored the detailed description of $S$. inclinatum from Modeo et al. (2003) due to the uncertainty of conspecificity for not sampling from the type locality (Baltic Sea) but from the Mediterranean Sea. 


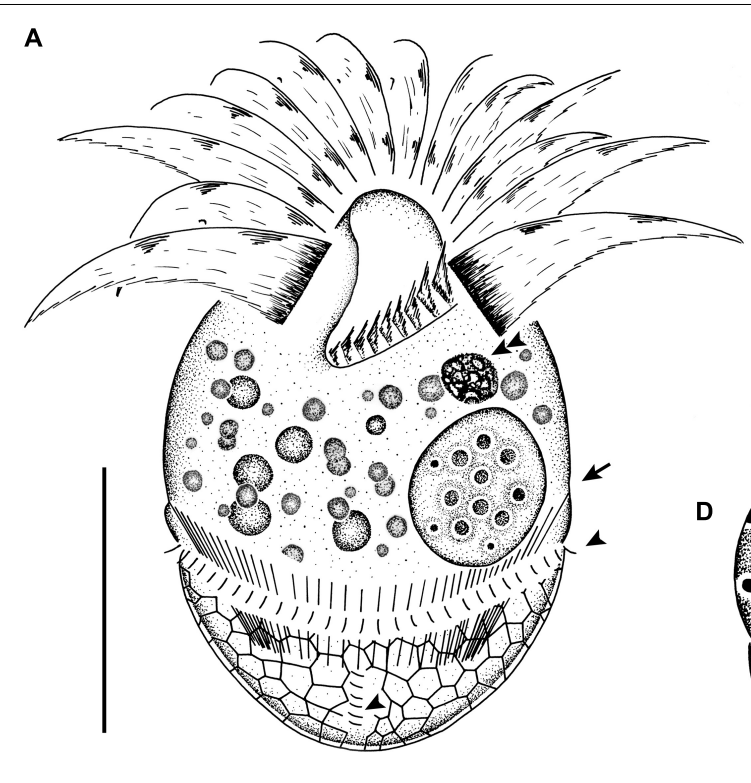

B

C
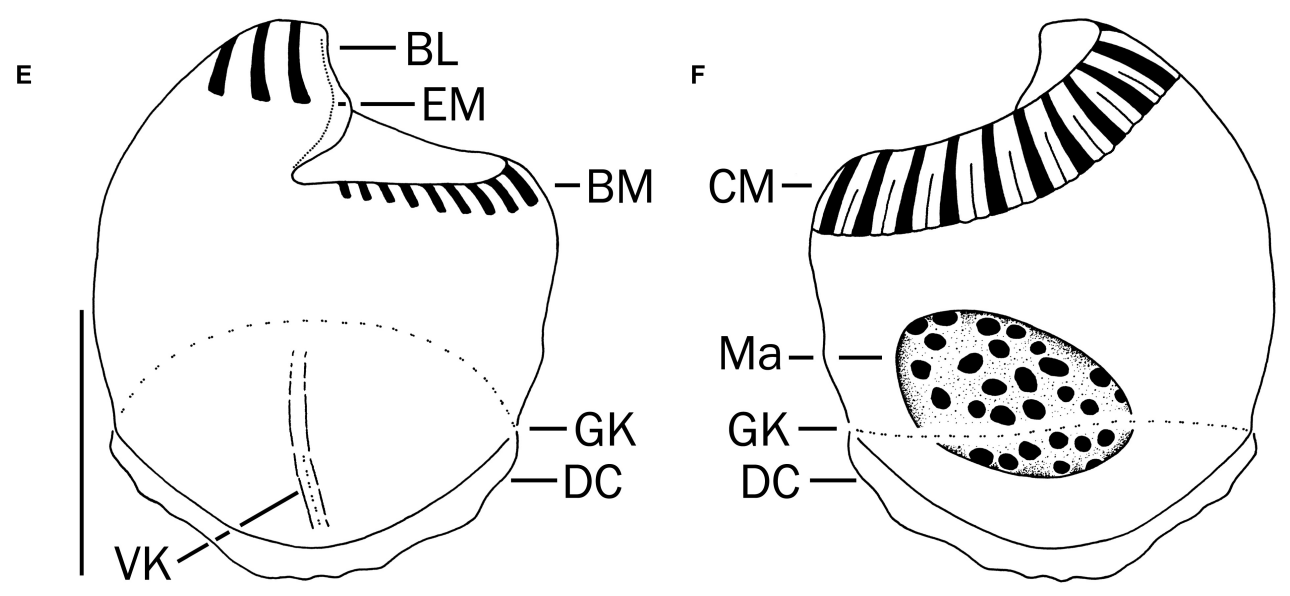

FIGURE 2 | Strombidium parasulcatum n. sp. from life (A-C) and after protargol impregnation (D-F). (A) Ventral view of a representative specimen, with an arrow indicating an extrusome, arrowheads marking the cilia on each left and each anterior basal body in the girdle kinety and ventral kinety, respectively. (B) Extrusomes. (C) Pattern of locomotion. (D) Macronuclei of diverse shapes. (E,F) Ventral and dorsal views of the holotype specimen. BL, buccal lip; BM, buccal membranelles; $\mathrm{CM}$, collar membranelles; DC, distended cell surface; EM, endoral membrane; GK, girdle kinety; Ma, macronucleus; VK, ventral kinety. Scale bars = 20 $\mu$ m (A,E,F) and $10 \mu \mathrm{m}$ (B).

Strombidium parasulcatum n. sp. differs from S. crassulum in cell size ( $35 \times 34$ vs. $62 \times 54 \mu \mathrm{m}$ after protargol staining), buccal cavity width (15 vs. $6 \mu \mathrm{m}$ ), the appearance of cortical platelets (vs. without), lack of an obvious gap in the ventral side of the girdle kinety (vs. with gap), and having fewer collar and buccal membranelles (13-16 vs. 16-19 and 7-10 vs. 13-19, respectively) and fewer dikinetids in the ventral and girdle kinety (4-8 vs. 9-15 and 55 vs. 115 , respectively).

Strombidium parasulcatum n. sp. can be distinguished from $S$. inclinatum by the cell size $(29-41 \times 27-40 \mu \mathrm{m}$ vs. $13-30 \times 13-$ $21 \mu \mathrm{m}$ ), the presence of an apical protrusion in vivo (vs. absent), buccal cavity width ( $15 \mathrm{vs} .4 \mu \mathrm{m}$ ), and the numbers of dikinetids in the girdle kinety (48-64 vs. 44-50).

Strombidium pseudostylifer and S. stylifer are characterized by having an elongate process/spine and can be easily separated from
S. parasulcatum n. sp. Moreover, S. parasulcatum can be separated from S. pseudostylifer and S. stylifer by the appearance of cortical platelets (vs. without), its shorter ventral kinety ( $6 \mu \mathrm{m}$ vs. 30 and $15 \mu \mathrm{m}$, respectively), and different numbers of dikinetids in the ventral kineties (4-8 vs. 17-29 and 7-14, respectively).

Strombidium parasulcatum n. sp. differs from S. suzukii in cell size $(35 \times 34$ vs. $55 \times 42 \mu \mathrm{m}$ after protargol staining), the appearance of cortical platelets (vs. without), shape of macronucleus (variable vs. globular), the size of macronucleus $(19 \times 11$ vs. $22 \times 17 \mu \mathrm{m})$, and having more buccal membranelles (7-10 vs. $6-7)$, fewer dikinetids in the ventral kinety ( $4-8$ vs. $15-$ 17), and a shorter ventral kinety ( 6 vs. $28 \mu \mathrm{m}$ measured from the line drawing in Figure 10.5G).

Strombidium parasulcatum n. sp. can be separated from S. sulcatum (Granda and Montagnes, 2003) by its larger cell 

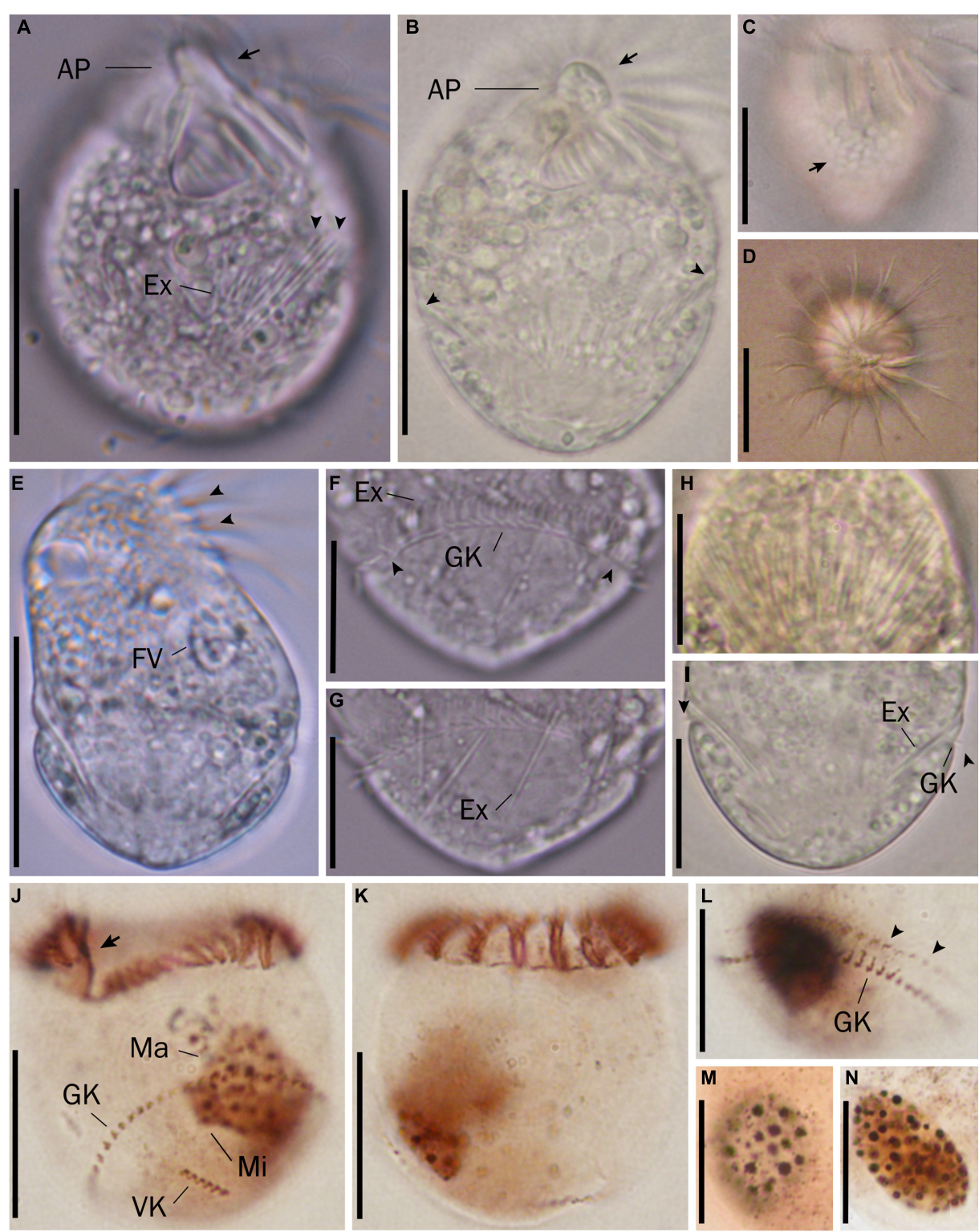

FIGURE 3 | Micrographs of Strombidium parasulcatum n. sp. from life (A-I) and after protargol impregnation (J-N). (A) Ventral view of the shorter specimen to show the apical protrusion (arrow) and the extrusomes (arrowheads). (B) Ventral view of a representative specimen to show the apical protrusion (arrow) and the bulge formed by the extrusome attachment sites (arrowheads). (C) Hemitheca, composed of polygonal platelets (arrow). (D) Apical view showing the apical protrusion and collar membranelles. (E) Dorsal view of a deformed specimen showing gaps between neighboring collar membranelles (arrowheads) and food vacuole. (F) Cilia of the girdle kinety (arrowheads). (G) Extrusomes with rounded anterior and pointed posterior end. (H) Extrusomes arranged probably in a single row, posteriorly extending obliquely into cytoplasm. (I) Cilia of the girdle kinety (arrowheads). (J,K) Ventral and dorsal views of the holotype specimen, with an arrow marking the endoral membrane. (L) Dorsal view showing the girdle kinety and the extrusome attachment sites (arrowheads). (M,N) Macronuclei of diverse shapes. AP, apical protrusion; Ex, extrusome; FV, food vacuole; GK, girdle kinety; Ma, macronucleus; VK, ventral kinety. Scale bars = $30 \mu \mathrm{m}$ (A-E), $20 \mu \mathrm{m}$ (J,K), and $15 \mu \mathrm{m}$ (F-I,L-N).

width (30-40 vs. $23 \mu \mathrm{m}$ in vivo), the disappearance of apical protrusion after protargol staining (vs. appearance with different staining methods), its larger buccal cavity width (15 vs. $7 \mu \mathrm{m})$, the shape of macronucleus (variable vs. bilobed), the arrangement of extrusomes (no-grouped vs. several in bundle), its shorter ventral kinety $(4-8 \mu \mathrm{m}$ vs. $10 \mu \mathrm{m})$, the position of the ventral kinety (occupying posterior $1 / 4$ of cell length vs. posterior $1 / 3$ of cell length), and different numbers of dikinetids in the girdle and ventral kineties (48-64 vs. $37-50$ and $4-8$ vs. 911 , respectively).

With reference to the general appearance and even the morphology characters commonly used for species distinguishing of genus Strombidium, it is difficult to separate the new species from S. sulcatum sensu Song et al. (2000) and Zhang et al. (2010). For example, they are similar in cell size, the appearance of anterior protrusion in vivo and after stained, 
TABLE 2 | Estimates of evolutionary distance between 18S rRNA gene sequences of six Strombidium species.

\begin{tabular}{|c|c|c|c|c|c|c|}
\hline & S. pseudostylifer & S. stylifer & S. crassulum & S. parasulcatum & S. inclinatum & S. sulcatum \\
\hline S. pseudostylifer & & 8 & 10 & 28 & 62 & 62 \\
\hline S. stylifer & 0.0048 & & 2 & 28 & 58 & 58 \\
\hline S. crassulum & 0.0060 & 0.0012 & & 28 & 58 & 58 \\
\hline S. parasulcatum & 0.0169 & 0.0169 & 0.0169 & & 76 & 76 \\
\hline S. inclinatum & 0.0375 & 0.0350 & 0.0351 & 0.0459 & & 0 \\
\hline S. sulcatum & 0.0375 & 0.0350 & 0.0351 & 0.0459 & 0.0000 & \\
\hline
\end{tabular}

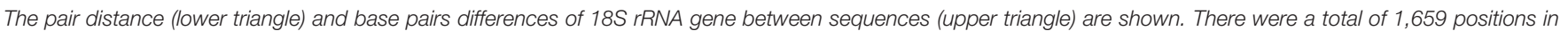
the final dataset. Evolutionary analyses were conducted in MEGA X, using the p-distance model.

TABLE 3 | Morphometrics comparison among species in the genus Strombidium.

\begin{tabular}{|c|c|c|c|c|c|c|c|c|}
\hline Characters & 1 & 2 & 3 & 4 & 5 & 6 & 7 & 8 \\
\hline Cell, length & $62(43-90)$ & $23(13-30)$ & $73(55-92)$ & $44(35-52)$ & $36(32-41)$ & $30-47$ & $55^{\star}$ & $35(29-41)$ \\
\hline Cell, width & $54(35-74)$ & $17(13-21)$ & $42(31-54)$ & $28(24-37)$ & $32(29-35)$ & $24-41$ & $42^{*}$ & $34(27-40)$ \\
\hline Anterior protrusion, in vivo & Inconspicuous & Absent & Present & Present & Present & Present & Conspicuous & Present \\
\hline Anterior protrusion, stained & Absent & Absent & Absent & Absent & Present & Absent & Present & Absent \\
\hline Buccal cavity, width & $6^{*}$ & $4^{*}$ & 22 & 17 & $7^{*}$ & $7^{*}$ & $15^{\star}$ & $15(11-20)$ \\
\hline Cortical platelets & Absent & Present & Absent & Absent & Present & Present & Absent & Present \\
\hline Macronucleus, length & $26(16-37)$ & $9(6-13)$ & $25(17-32)$ & $19(13-26)$ & $14(12-17)$ & $16^{*}$ & $22^{*}$ & $19(10-28)$ \\
\hline Macronucleus, width & $22(13-28)$ & $9(6-13)$ & $21(15-30)$ & $15(7-25)$ & $12(9-13)$ & $13^{*}$ & $17^{\star}$ & $11(8-14)$ \\
\hline Collar membranelles, number & $17(16-19)$ & $14(12-15)$ & $15(14-17)$ & $15(13-17)$ & $15(14-15)$ & $13-16$ & $15-16$ & $15(13-16)$ \\
\hline Buccal membranelles, number & $15(13-19)$ & $8(7-9)$ & $8(7-9)$ & $8(5-9)$ & $7(6-9)$ & $7-9$ & $6-7$ & $9(7-10)$ \\
\hline Girdle kinety, no. of dikinetids & 115 & $44-50^{\star}$ & $45(36-53)$ & $46(38-58)$ & $44(37-50)$ & $50(46-56)$ & $50-66$ & $55(48-64)$ \\
\hline Girdle kinety, gap & Ventral side & Absent & Absent & Absent & Absent & Absent & Absent & Absent \\
\hline Ventral kinety, no. of dikinetids & $11(9-15)$ & $7-9$ & $23(17-29)$ & $10(7-14)$ & $10(9-11)$ & $5-12$ & $15-17$ & $7(4-8)$ \\
\hline Ventral kinety, length & $9^{*}$ & $5^{\star}$ & 30 & $15^{\star}$ & $10^{\star}$ & $7^{\star}$ & $28^{\star}$ & $6(4-8)$ \\
\hline Elongate process/spine & Absent & Absent & Present & Present & Absent & Absent & Absent & Absent \\
\hline
\end{tabular}

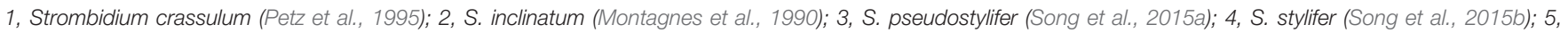
S. sulcatum (Granda and Montagnes, 2003); 6, S. sulcatum (Song et al., 2000); 7, S. suzukii (Xu et al., 2009); 8, S. parasulcatum (this study).

Measurements were made on protargol-impregnated specimens and are presented as means (range). Measurements in $\mu m$.

*Data were obtained from the figures in the original work.

number of collar and buccal membranelles, number of dikinetids of girdle and ventral kinety, and length of ventral kinety. However, the low similarity of the 18S rRNA gene sequences between them demonstrates that they cannot be conspecific. Moreover, their dissimilarities in terms of the position of the largest cell width (equatorial area vs. posterior of mid-body), the width and depth of buccal cavity ( $15 \mathrm{vs} .7 \mu \mathrm{m}$ and $25 \mathrm{vs.} 33 \%$ of cell length), arrangement of extrusomes (no-grouped vs. several in bundle), the position of girdle kinety (posterior one-third vs. mid-body), and the length of cilia in collar membranelles ( $25 \mathrm{vs.}$ $20 \mu \mathrm{m}$ ) justify naming our organism as a separate species.

\section{Establishment of Cryptic Species}

Given that the high morphology similarities with its congeners, $S$. parasulcatum could be regarded as a cryptic species. The discrimination of cryptic species (morphologically indistinguishable forms that appear to be genetically distinct) has become an urgent issue for taxonomists. To resolve this issue, previous studies suggested that the subtle morphological or ecological differences among the species are required, so we can understand their biogeography and ecological niche differentiation (McManus et al., 2010).
Moreover, the ultrastructure and cyst morphology should also be considered (Gruber et al., 2019). However, our study showed that the molecular data could play an important part in the resolution of the cryptic species, as suggested by Santoferrara and McManus (2017).

\section{Comparison With Similar Congeners' Growth Rates}

Some of oligotrich ciliates have the ability to consume bacteria (Rivier et al., 1985; Bernard and Rassoulzadegan, 1990). Previous studies showed that $S$. sulcatum can graze on pico-sized prey, including live bacteria, heat-killed bacteria, fluorescently labeled bacteria (FLB), and non-living, bacteria-size particles (Fenchel and Jonsson, 1988; Allali et al., 1994; Dolan and Šimek, 1997; Christaki et al., 1998; Dolan, 2018). Neglect of the first 1-day growth rate with negative value in the present study, the growth rate of $S$. parasulcatum grazing on bacteria at the second $24 \mathrm{~h}$ cultivation was lower than that of S. sulcatum observed by Rivier et al. (1985) in $24 \mathrm{~h}$ incubation (about 1.06 vs. $1.56-2.33$ day $^{-1}$ ), although it showed its highest 1-day specific growth rates beginning at day $5\left(1.79 \mathrm{day}^{-1}\right)$. The findings demonstrate that both congeners have different trophodynamic parameters. 

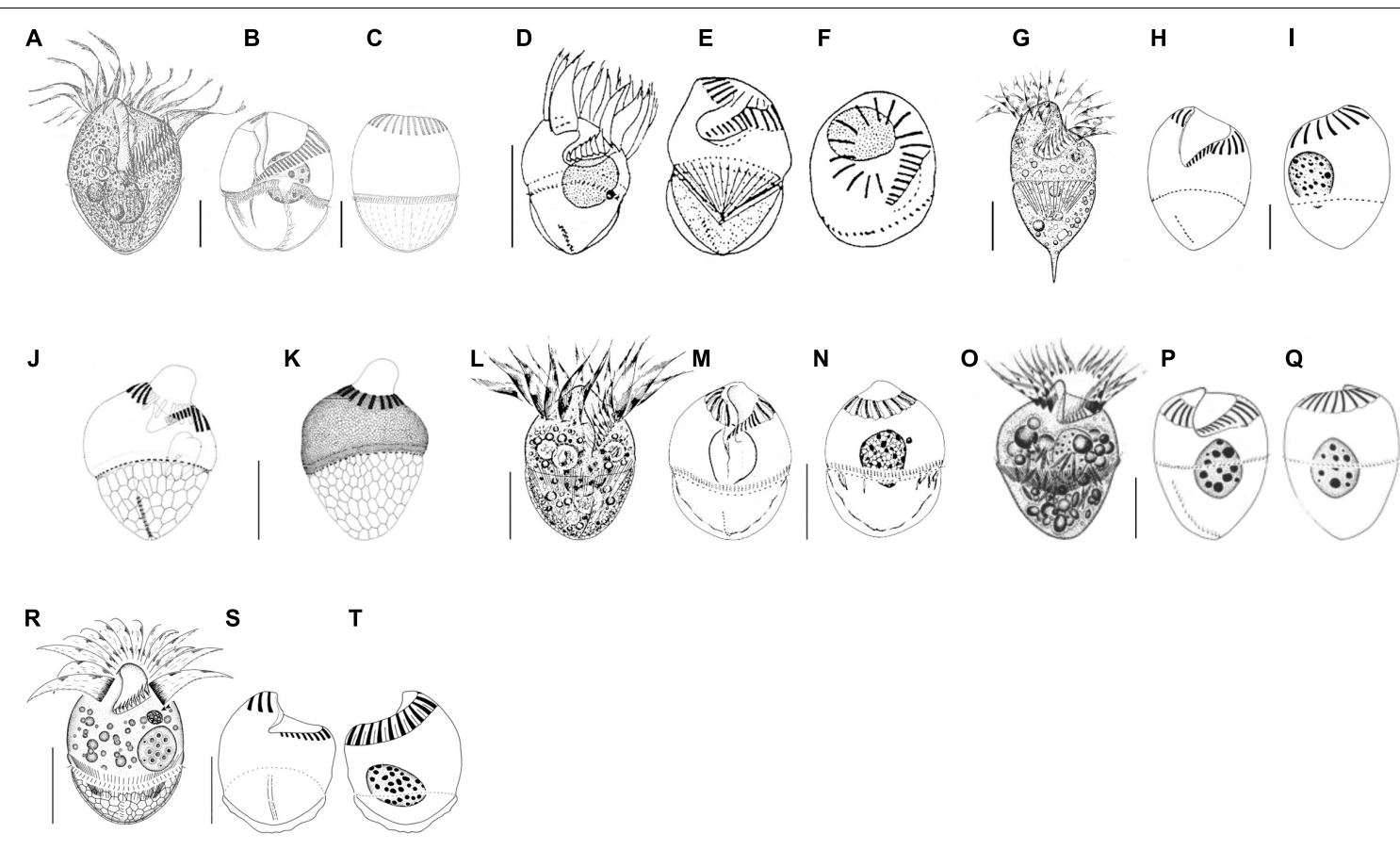

FIGURE 4 | Schematic drawings of seven species compared in Table $\mathbf{3}$ from life (A,D,G,L,O,R) and after protargol impregnation (B,C,E,F,H-K,M,N,P,Q,S,T). (A-C) Strombidium crassulum (Petz et al., 1995); (D-F) S. inclinatum (Montagnes et al., 1990); (G-I) S. stylifer (Song et al., 2015b); (J,K) S. sulcatum (Granda and Montagnes, 2003); (L-N) S. sulcatum (Song et al., 2000); (O-Q) S. suzukii (Xu et al., 2009); (R-T) S. parasulcatum (this study). Scale bar: $20 \mu \mathrm{m}$.

\section{Comments on the Phylogenetic Analysis}

Five congeners are closely related to S. parasulcatum according to the phylogenetic tree (Figure 1). Although S. parasulcatum groups with S. crassulum, S. pseudostylifer, and S. stylifer (MP, $100 \%$; BI, 1.00), it is morphologically distinct from these three species (Table 3), i.e., S. parasulcatum differs from S. stylifer and $S$. pseudostylifer in the absence (vs. presence) of an elongated process/spine and can be distinguished from $S$. crassulum by the different numbers of dikinetids in the girdle and ventral kinety (48-64 vs. 115 and $4-8$ vs. 9-15, respectively). Strombidium parasulcatum has high similarity with $S$. sulcatum and S. inclinatum in morphology, but they do not cluster together in the phylogenetic tree, and their $18 \mathrm{~S}$ rRNA gene sequences show high dissimilarity compared with S. pseudostylifer, S. stylifer, and S. crassulum. All six congeners belong to the same clade, so more gene sequences and other gene markers are needed in order to resolve the phylogenetic relationships among these taxa and to identity morphological synapomorphies.

\section{TAXONOMIC SUMMARY}

Class Oligotrichea Bütschli, 1889

Subclass Oligotrichia Bütschli, 1889

Order Oligotrichida Bütschli, 1889

Family Strombidiidae Fauré-Fremiet, 1970

Genus Strombidium Claparède and Lachmann, 1859

Strombidium parasulcatum n. sp.
Diagnosis. Cell $40-50 \times 30-40 \mu \mathrm{m}$ in vivo, slightly variable in shape, generally broadly obconical to ellipsoidal with apical protrusion. Macronucleus variable, spherical to ellipsoidal. Adoral zone split into 15 collar and 9 buccal membranelles. Girdle kinety equatorial, continuous, composed of about 55 dikinetids. Ventral kinety extending meridionally in posterior one-fourth of cell ventral, composed of about seven dikinetids.

Type locality. Coastal waters off Keelung $\left(25^{\circ} 08^{\prime} 30^{\prime \prime} \mathrm{N} ; 121^{\circ}\right.$ $47^{\prime} 42^{\prime \prime}$ E), Taiwan.

Type material. The holotype with protargol-impregnated specimen is deposited in the Biodiversity Research Center, Academia Sinica, Taipei, Taiwan, ROC (ASIZ01000005). The paratype specimens are deposited in the Natural History Museum, London, United Kingdom (NHMUK 2014.1.8.1).

Gene sequence. The accession number for the 18S rRNA gene sequence of Strombidium parasulcatum in the GenBank database is KJ101609.

Etymology. From para, Greek for beside, combined with sulcatum. Neuter gender.

Zoobank registration. urn:lsid:zoobank.org:pub:428672C2A57E-46E9-BBEC-EF2669B85FF7.

\section{DATA AVAILABILITY STATEMENT}

The datasets presented in this study can be found in online repositories. The names of the repository/repositories 
and accession number(s) can be found below: NCBI (accession: KJ101609).

\section{AUTHOR CONTRIBUTIONS}

S-FT and K-PC conceived the research. S-FT, K-PC, and M-LL conducted the analysis and drafted the manuscript. All authors contributed to the article and approved the submitted version.

\section{FUNDING}

This study was supported by grants from the Ministry of Science and Technology, Taiwan, ROC (105-2313-B-019-004, 105-2611M-019-008, and 106-2611-M-019-023).

\section{REFERENCES}

Agatha, S. (2011a). Updated hypothesis on the evolution of oligotrichid ciliates (Ciliophora, Spirotricha, Oligotrichida) based on somatic ciliary patterns and ontogenetic data. Eur. J. Protistol. 47, 51-56. doi: 10.1016/j.ejop.2010.09.001

Agatha, S. (2011b). Global diversity of aloricate Oligotrichea (Protista, Ciliophora, Spirotricha) in marine and brackish sea water. PLoS One 6:e22466. doi: 10.1371/ journal.pone.0022466

Agatha, S., Ganser, M. H., and Santoferrara, L. F. (2021). The importance of type species and their correct identification: a key example from tintinnid ciliates (Alveolata, Ciliophora, Spirotricha). J. Eukaryot. Microbiol. 68:e12865. doi: $10.1111 /$ jeu. 12865

Agatha, S., and Riedel-Lorjé, J. C. (2006). Redescription of Tintinnopsis cylindrica Daday, 1887 (Ciliophora: spirotricha) and unification of tintinnid terminology. Acta Protozool. 45, 137-151.

Agatha, S., and Strüder-Kypke, M. C. (2007). Phylogeny of the order Choreotrichida (Ciliophora, Spirotricha, Oligotrichea) as inferred from morphology, ultrastructure, ontogenesis, and SSrRNA gene sequences. Eur. J. Protistol. 43, 37-63. doi: 10.1016/j.ejop.2006. 10.001

Agatha, S., and Strüder-Kypke, M. C. (2014). What morphology and molecules tell us about the evolution of Oligotrichea (Alveolata, Ciliophora). Acta Protozool. $53,77-90$.

Agatha, S., Strüder-Kypke, M. C., Beran, A., and Lynn, D. H. (2005). Pelagostrobilidium neptuni (Montagnes and Taylor, 1994) and Strombidium biarmatum nov. spec. (Ciliophora, Oligotrichea): phylogenetic position inferred from morphology, ontogenesis, and gene sequence data. Eur. J. Protistol. 41, 65-83. doi: 10.1016/j.ejop.2004.09.005

Allali, K., Dolan, J., and Rassoulzadegan, F. (1994). Culture characteristics and orthophosphate excretion of a marine oligotrich ciliate, Strombidium sulcatum, fed heat-killed bacteria. Mar. Ecol. Prog. Ser. 105, 159-165. doi: 10.3354/ meps 105159

Bernard, C., and Rassoulzadegan, F. (1990). Bacteria or microflagellates as a major food source for marine ciliates: possible implications for the microzooplankton. Mar. Ecol. Prog. Ser. 64, 147-155.

Bojanić, N., Vidjak, O., and Brautović, I. (2006). Spatial and temporal variability in abundance and biomass of oligotrich ciliates in Kaštela Bay (middle Adriatic Sea). Acta Adriat. 47, 93-109.

Chen, X., Shao, C., Lin, X., Clamp, J. C., and Song, W. (2013). Morphology and molecular phylogeny of two new brackish-waterspecies of Amphisiella (Ciliophora Hypotrichia), with notes on morphogenesis. Eur. J. Protistol. 49, 453-466. doi: 10.1016/j.ejop.2012.11.002

Christaki, U., Dolan, J. R., Pelegri, S., and Rassoulzadegan, F. (1998). Consumption of picoplankton-size particles by marine ciliates: effects of physiological state of the ciliate and particle quality. Limnol. Oceanogr. 43, 458-464. doi: 10.4319/lo. 1998.43.3.0458

Dolan, J. R. (2018). The Villefranche Strombidium sulcatum: a review. Eur. J. Protistol. 66, 68-76. doi: 10.1016/j.ejop.2018.08.002

\section{ACKNOWLEDGMENTS}

Many thanks are given to George B. McManus (Department of Marine Sciences, University of Connecticut, United States) and Mark J. Grygier (Center of Excellence for the Oceans, National Taiwan Ocean University, Taiwan) for their constructive criticism and linguistic improvements. We also thank the editor and reviewers for their many insightful comments and suggestions.

\section{SUPPLEMENTARY MATERIAL}

The Supplementary Material for this article can be found online at: https://www.frontiersin.org/articles/10.3389/fmicb. 2021.770768/full\#supplementary-material

Dolan, J. R., and Šimek, K. (1997). Processing of ingested matter in Strombidium sulcatum, a marine ciliate (Oligotrichida). Limnol. Oceanogr. 42, 393-397. doi: 10.4319/lo.1997.42.2.0393

Fauré-Fremiet, E. (1912). Sur le mode de division du Strombidium sulcatum cl. et Lach. Bull. Soc. Zool. Fr. 36, 207-208.

Fauré-Fremiet, E., and Ganier, M.-C. (1970). Structure fine du Strombidium sulcatum Cl. et L. (Ciliata Oligotrichida). Protistologica 6, 207-223.

Fenchel, T., and Jonsson, P. R. (1988). The functional biology of Strombidium sulcatum, a marine oligotrich ciliate (Ciliophora, Oligotrichina). Mar. Ecol. Prog. Ser. 48, 1-15. doi: 10.3354/meps048001

Fileman, E. S., and Leakey, R. J. G. (2005). Microzooplankton dynamics during the development of the spring bloom in the north-east Atlantic. J. Mar. Biol. Assoc. U. K. 85, 741-753. doi: 10.1017/s0025315405011653

Foissner, W. (1994). Progress in taxonomy of planktonic freshwater ciliates. Mar. Microb. Food Webs 8, 9-35.

Gao, S., Gong, J., Lynn, D. H., Lin, X., and Song, W. (2009). An updated phylogeny of oligotrich and choreotrich ciliates (Protozoa, Ciliophora, Spirotrichea) with representative taxa collected from Chinese coastal waters. Syst. Biodivers. 7, 235-242.

Granda, A. P., and Montagnes, D. J. S. (2003). An improved description of Strombidium sulcatum Claparède \& Lachmann, 1859 (Ciliophora) from slides of Fauré-Fremiet, and a designation of type material. J. Eukaryot. Microbiol. 50, 422-426.

Gruber, M., Alexandra, M., and Agatha, S. (2019). Ultrastructural Studies on a Model Tintinnid - Schmidingerella meunieri (Kofoid and Campbell, 1929) Agatha and Strüder-Kypke, 2012 (Ciliophora). I. Somatic Kinetids with Unique Ultrastructure. Acta Protozool. 57, 195-213. doi: 10.4467/16890027AP.18.015. 10091

Hasle, G. R. (1978). “The inverted-microscope method” in Phytoplankton Manual, ed. A. Sournia (Paris: UNESCO), 88-96.

Huelsenbeck, J. P., and Ronquist, F. (2001). MRBAYES: bayesian inference of phylogenetic trees. Bioinformatics 17, 754-755. doi: 10.1093/bioinformatics/17. 8.754

Katz, L. A., McManus, G. B., Snoeyenbos-West, O. L. O., Griffin, A., Pirog, K., Costas, B., et al. (2005). Reframing the 'Everything is everywhere' debate: evidence for high gene flow and diversity in ciliate morphospecies. Aquat. Microb. Ecol. 41, 55-65. doi: 10.3354/ame041055

Kim, S. Y., Yang, E. J., Gong, J., and Choi, J. K. (2010). Redescription of Favella ehrenbergii (Claparède and Lachmann, 1858) Jörgensen, 1924 (Ciliophora: choreotrichia), with phylogenetic analyses based on Small Subunit rRNA gene sequences. J. Eukaryot. Microbiol. 57, 460-467. doi: 10.1111/j.1550-7408.2010. 00500.x

Li, J., Liu, W., Gao, S., Warren, A., and Song, W. (2013). Multigene-based analyses of the phylogenetic evolution of oligotrich ciliates, with consideration of the Internal Transcribed Spacer 2 secondary structure of three systematically ambiguous genera. Eukaryot. Cell 12, 430-437. doi: 10.1128/EC.00270-12

Liu, W., Jiang, J., Xu, Y., Pan, X., Qu, Z., Luo, X., et al. (2017). Diversity of freeliving marine ciliates (Alveolata, Ciliophora): faunal studies in coastal waters of 
China during the years 2011-2016. Eur. J. Protistol. 61, 424-438. doi: 10.1016/j. ejop.2017.04.007

Liu, W., Xu, D., Lin, X., Li, J., Gong, J., Al-Rasheid, K. A. S., et al. (2009). Novistrombidium sinicum n. sp. and Novistrombidium orientale n. sp. (Protozoa: ciliophora): two new oligotrich ciliates from a mangrove wetland, South China. J. Eukaryot. Microbiol. 56, 459-465. doi: 10.1111/j.1550-7408.2009.00425.x

Liu, W., Yi, Z., Lin, X., and Al-Rasheid, K. A. S. (2011a). Morphologic and molecular data suggest that Lynnella semiglobulosa $\mathrm{n}$. g., n. sp. represents a new family within the Subclass Choreotrichia (Ciliophora, Spirotrichea). J. Eukaryot. Microbiol. 58, 43-49. doi: 10.1111/j.1550-7408.2010.00519.x

Liu, W., Yi, Z., Warren, A., Al-Rasheid, K. A. S., Al-Farraj, S. A., Lin, X., et al. (2011b). Taxonomy, morphology and molecular systematics of a new oligotrich ciliate, Williophrya maedai gen. nov., sp. nov., with redescriptions of Strombidium basimorphum and Pseudotontonia simplicidens (Protozoa, Ciliophora, Oligotrichia). Syst. Biodivers. 9, 247-258. doi: 10.1080/14772000. 2011.605812

Liu, W., Yi, Z., Lin, X., Li, J., Al-Farraj, S. A., Al-Rasheid, K. A. S., et al. (2015). Morphology and molecular phylogeny of three new oligotrich ciliates (Protozoa, Ciliophora) from the South China Sea. Zool. J. Linn. Soc. 174, 653-665.

Maeda, M. (1986). An illustrated guide to the species of the Families Halteriidae and Strobilidiidae (Oligotrichida, Ciliophora), free swimming protozoa common in the aquatic environment. Bull. Ocean Res. Inst. Univ. Tokyo 21, 1-67. doi: 10.1007/978-3-319-23534-9_1

Maeda, M., and Carey, P. G. (1985). An illustrated guide to the species of the family Strombidiidae (Oligotrichida, Ciliophora), free swimming protozoa common in the aquatic environment. Bull. Ocean Res. Inst. Univ. Tokyo 19, 1-68. doi: $10.15625 / 2615-9023 / 15888$

McManus, G. B., Xu, D., Costas, B., and Katz, L. A. (2010). Genetic identities of cryptic species in the Strombidium stylifer/apolatum/oculatum cluster, including a description of Strombidium rassoulzadegani n. sp. J. Eukaryot. Microbiol. 57, 369-378. doi: 10.1111/j.1550-7408.2010.00485.x

Medlin, L., Elwood, H. J., Stickel, S., and Sogin, M. L. (1988). The characterization of enzymatically amplified eukaryotic 16Slike rRNA-coding regions. Gene 71, 491-499. doi: 10.1016/0378-1119(88)90066-2

Mitra, A., Flynn, K. J., Tillmann, U., Raven, J. A., Caron, D., Stoecker, D. K., et al. (2016). Defining planktonic protist functional groups on mechanisms for energy and nutrient acquisition: incorporation of diverse mixotrophic strategies. Protist 167, 106-120. doi: 10.1016/j.protis.2016.01.003

Modeo, L., Petroni, G., Rosati, G., and Montagnes, D. J. S. (2003). A multidisciplinary approach to describe protists: redescriptions of Novistrombidium testaceum Anigstein 1914 and Strombidium inclinatum Montagnes, Taylor, and Lynn 1990 (Ciliophora, Oligotrichia). J. Eukaryot. Microbiol. 50, 175-189. doi: 10.1111/j.1550-7408.2003.tb00114.x

Montagnes, D. J. S., and Lynn, D. H. (1991). Taxonomy of choreotrichs, the major marine planktonic ciliates, with emphasis on the aloricate forms. Mar. Microb. Food Webs 5, 59-74.

Montagnes, D. J. S., Taylor, F. J. R., and Lynn, D. H. (1990). Strombidium inclinatum n. sp. and a reassessment of Strombidium sulcatum Claparède and Lachmann (Ciliophora). J. Protozool. 37, 318-323. doi: 10.1111/j.1550-7408.1990.tb01152.x

Petz, W., Song, W., and Wilbert, N. (1995). Taxonomy and ecology of the ciliate fauna (Protozoa, Ciliophora) in the endopagial and pelagial of the Weddell Sea, Antarctica. Stapfia 40, 1-223. doi: 10.1007/978-3-319-23534-9_1

Pierce, R. W., and Turner, J. T. (1992). Ecology of planktonic ciliates in marine food webs. Rev. Aquat. Sci. 6, 139-181.

Porter, K. G., and Feig, Y. S. (1980). The use of DAPI for identifying and counting aquatic microflora. Limnol. Oceanogr. 25, 943-948. doi: 10.4319/lo.1980.25.5. 0943

Posada, D., and Crandall, K. A. (1998). MODELTEST: testing the model of DNA substitution. Bioinformatics 14, 817-818. doi: 10.1093/bioinformatics/14.9.817

Qu, Z., Pan, H., Hu, X., Li, J., Al-Farraj, S. A., Al-Rasheid, K. A. S., et al. (2015). Morphology and molecular phylogeny of three cyrtophorid ciliates (Protozoa, Ciliophora) from China, including two new species, Chilodonella parauncinata sp. n. and Chlamydonella irregularis sp. n. J. Eukaryot. Microbiol. 62, 267-279. doi: $10.1111 /$ jeu. 12175

Rivier, A., Brownlee, D. C., Sheldon, R. W., and Rassoulzadegan, F. (1985). Growth of microzooplankton: a comparative study of bactivorous zooflagellates and ciliates. Mar. Microb. Food Webs 1, 51-60.

Santoferrara, L. F., and McManus, G. B. (2017). Integrating dimensions of biodiversity in choreotrichs and oligotrichs of marine plankton. Eur. J. Protistol. 61,323-330. doi: 10.1016/j.ejop.2017.04.004
Song, W., Li, J., Liu, W., Al-rasheid, K. A. S., Hu, X., and Lin, X. (2015a). Taxonomy and molecular phylogeny of four Strombidium species, including description of S. pseudostylifer sp. nov. (Ciliophora, Oligotrichia). Syst. Biodivers. 13, 76-92.

Song, W., Zhao, X., Liu, W., Hu, X., Al-Farraj, S. A., Al-Rasheid, K. A. S., et al. (2015b). Biodiversity of oligotrich ciliates in the South China Sea: description of three new Strombidium species (Protozoa, Ciliophora, Oligotrichia) with phylogenetic analyses. Syst. Biodivers. 13, 608-623. doi: 10.1080/14772000.2015. 1081992

Song, W. B., Wang, M., and Warren, A. (2000). Redescriptions of three marine ciliates, Strombidium elegans Florentin, 1901, Strombidium sulcatum Claparède \& Lachmann, 1859 and Heterostrombidium paracalkinsi Lei, Xu \& Song, 1999 (Ciliophora, Oligotrichida). Eur. J. Protistol. 36, 327-342. doi: 10.1016/s09324739(00)80010-3

Song, W. B., and Wilbert, N. (1995). "Benthische Ciliaten des Süßwassers," in Praktikum der Protozoologie, ed. R. Röttger (Stuttgart: Gustav Fischer Verlag), 156-168.

Strüder-Kypke, M. C., and Lynn, D. H. (2008). Morphological versus molecular data - phylogeny of tintinnid ciliates (Ciliophora, Choreotrichia) inferred from small subunit rRNA gene sequences. Denisia 23, 417-424.

Swofford, D. L. (2002). PAUP*. Phylogenetic Analysis Using Parsimony (* and Other Methods). Version 4.0b10. Sunderland: Sinauer Associates.

Thompson, J. D., Higgins, D. G., and Gibson, T. J. (1994). CLUSTAL alignment through sequence weighting, positions-specific gap penalties and weight matrix choice. Nucleic Acids Res. 22, 4673-4680. doi: 10.1093/nar/22.22.4673

Tsai, S. F., Chen, J. Y., and Chiang, K. P. (2010). Spirotontonia taiwanica n. sp. (Ciliophora: oligotrichida) from the coastal waters of northeastern Taiwan: morphology and nuclear Small Subunit rDNA sequence. J. Eukaryot. Microbiol. 57, 429-434. doi: 10.1111/j.1550-7408.2010.00494.x

Tsai, S.-F., Chen, W.-T., and Chiang, K.-P. (2015). Phylogenetic position of the genus Cyrtostrombidium, with a description of Cyrtostrombidium paralongisomum nov. spec. and a redescription of Cyrtostrombidium longisomum Lynn \& Gilron, 1993 (Protozoa, Ciliophora) based on live observation, protargol impregnation, and $18 \mathrm{~S}$ rDNA sequences. J. Eukaryot. Microbiol. 62, 239-248. doi: 10.1111/jeu.12173

Tsai, S. F., Xu, D., Chung, C. C., and Chiang, K. P. (2008). Parastrombidinopsis minima n. sp. (Ciliophora: oligotrichia) from the coastal waters of northeastern Taiwan: morphology and small subunit ribosomal DNA sequence. J. Eukaryot. Microbiol. 55, 567-573. doi: 10.1111/j.1550-7408.2008.00364.x

Warren, A., Patterson, D. J., Dunthorn, M., Clamp, J. C., Achilles-Day, U. E. M., Aescht, E., et al. (2017). Beyond the "Code": a guide to the description and documentation of biodiversity in ciliated protists (Alveolata, Ciliophora). J. Eukaryot. Microbiol. 64, 539-554. doi: 10.1111/jeu.12391

Xu, D., Sun, P., Clamp, J. C., Ma, H., and Song, W. (2011). The establishment of a new oligotrich genus Varistrombidium gen. nov. and the morphology and phylogeny of a marine ciliate, Varistrombidium kielum (Maeda and Carey, 1985) nov. comb. (Protista, Ciliophora). Acta Zootaxon. Sin. 36, 502-511.

Xu, D., Warren, A., and Song, W. (2009). "Oligotrichs," in Free-living ciliates in the Bohai and Yellow Seas, China, eds W. Song, A. Warren, and X. Hu (Beijing: Science Press), 307-351.

Zhang, Q., Yi, Z., Xu, D., Al-Rasheid, K. A. S., Gong, J., and Song, W. (2010). Molecular phylogeny of oligotrich genera Omegastrombidium and Novistrombidium (Protozoa, Ciliophora) for the systematical relationships within Family Strombidiidae. Chin. J. Oceanol. Limnol. 28, 769-777.

Conflict of Interest: The authors declare that the research was conducted in the absence of any commercial or financial relationships that could be construed as a potential conflict of interest.

Publisher's Note: All claims expressed in this article are solely those of the authors and do not necessarily represent those of their affiliated organizations, or those of the publisher, the editors and the reviewers. Any product that may be evaluated in this article, or claim that may be made by its manufacturer, is not guaranteed or endorsed by the publisher.

Copyright (C) 2022 Tsai, Lee and Chiang. This is an open-access article distributed under the terms of the Creative Commons Attribution License (CC BY). The use, distribution or reproduction in other forums is permitted, provided the original author(s) and the copyright owner(s) are credited and that the original publication in this journal is cited, in accordance with accepted academic practice. No use, distribution or reproduction is permitted which does not comply with these terms. 